\title{
Sosyal Medya ile Kurumsal İtibar Oluşturma
}

\author{
Esra SIPAHi ${ }^{1}$ \\ Erkin ARTANTAŞ²
}

\section{Öz}

21. yüzyılda teknolojik gelişmelerin etkisi ile koşullar değişmiş ve her geçen gün değişmeye devam etmektedir. İşletmeler küresel rekabet ortamında ayakta kalabilmek ve varlıklarını sürdürebilmeye çalışmaktadırlar. Bunu sağlamanın en önemli araçlarından birisi de örgütlerin stratejik halkla ilişkiler fonksiyonu ve bu fonksiyonun en önemli işlevlerinden olan kurumsal itibar yönetimidir. Son yıllarda sosyal medya da her alanda kullanılmaya başlanmıştır. Kurumlar da birer birer sosyal medyaya yönelmiş bu ortamlarda da kurumsal itibarlarını geliştirecek çalışmalar yapmaktadırlar. Bu noktada sosyal medyanın kurumlar tarafından etkin bir şekilde kullanılıp kullanılmadığı, itibar açısından son derece önemli olmaktadır. Bu makalede kurumsal itibar oluşma ve sosyal medya ilişkisi araştırılmıştır.

Anahtar Kelimeler: Sosyal Medya, Yeni Medya, İtibar, Kurumsal i̇tibar, Facebook.

\section{Creating Corporate Reputation with Social Media}

\begin{abstract}
With the effect of technological developments in the 21st century, conditions have changed and they continue to change day by day. Businesses are working to be able to survive in the global competition and maintain their existence. One of the most important means of achieving this is the strategic public relations function of the organizations and the corporate reputation management which is one of the most important functions of this function. In recent years, social media has started to be used in all areas. Institutions are also directed to social media and work to improve their corporate reputation in these environments. At this point, whether or not the fact that social media is used effectively by institutions is of utmost importance in terms of reputation. In this article, corporate reputation formation and social media relations were studied.
\end{abstract}

Keywords: Social media, New Media, Corporate, Corporate Reputation, Facebook

\footnotetext{
1 İstanbul Gelisim Üniversitesi / İsletme Doktora Ögrencisi, sipahiesra@ hotmail.com

2 İstanbul Gelisim Üniversitesi / İsletme Doktora Ögrencisi, erkins71@ @otmail.com
} 


\section{Gíriș}

Kurumların artan rekabet ortamında var olabilmeleri ve varlıklarını devam ettirebilmeleri için güçlü bir itibar oluşturması gerekmektedir.

İnternetin gelişimiyle birlikte kurumlar da değişmiştir. Sosyal medyanın gelişmesi ve beraberinde internetin gündelik hayatımızda her an bağlantılı olmasıyla birlikte ortaya çıkan bu yeni medya akımı, kuruluşların itibarını olumlu ya da olumsuz yönde etkileme noktasında önemli bir unsur olmaktadır.

Küresel rekabet ortamında bu gelişime ayak uyduran kurumların diğer kurumlara göre daha ön sıralarda yer almaları kuşkusuzdur. Kurumlar, rekabetçi bir pazar ortamında başarılı olabilmek için, tüketicileri memnun etmek amacıyla sürekli yeni stratejiler geliştirmektedir. İnternetin yaygınlık kazanmasıyla birlikte tüketicilerle çevrimiçi iletişim kurmak kritik önem taşımaktadır. Kurumlar sosyal medya ortamında kurumsal itibarı oluşturma, büyütme ve koruma amacıyla adımlar içeren stratejiler üretmelidir.

Kurumsal itibar konusuyla ilgili literatür incelendiğinde kurum itibarı ve

${ }^{1}$ Erkan Akar, Sosyal Medya Pazarlaması, Ankara: Efil yayınevi, 2010, s.43.

${ }^{2}$ Maria Azua, The Social factor-Immovate, Ignite and Win through Mass sosyal medya arasındaki ilişkiyi konu alan çalışmalara Türkiye'de çok az yer verildiği görülmektedir. Bu bağlamda çalışmanın amacı gündelik hayatımızın ayrılmaz bir parçası haline gelen sosyal medyanın, kurumsal itibar açısından taşıdığı stratejik önemi ortaya koymaktır.

$\mathrm{Bu}$ kapsamda bu makalenin hem Türkiye'de ilgili konudaki boşluğu dolduracağı hem de konuyla ilgili ileride yapılması planlanan araştırmalara katkı sağlayabileceği düşünülmektedir.

\section{TÜRKIYE VE SOSYAL MEDYA}

Televizyonun icadı bilgi devrinin başlangıç dönemi olarak kabul edilmesine karşın, bilgisayarın keşfi ve kişisel bilgisayarların geliştirilmesi söz konusu devrin ilerleyiş sürecini hızlandırarak sosyal devrin oluşumuna zemin hazırlamıştır'. 21.asrın başlangıcıyla beraber bilgi devri yerini sosyal devre bırakmış olup, akıllı elektronik cihazlar hızlı bir popülarite kazanmıştır. Şekil 1'de tarihsel dönemler, söz konusu dönemlere ait araçlar ve azalış gösteren iletişim maliyetleri verilmektedir².

Collaboration and Social Networking, IBM Press: NJ, 2010, s.64. 
Şekil 1: Modern tarihsel çağlar, araçları ve iletişim maliyetleri

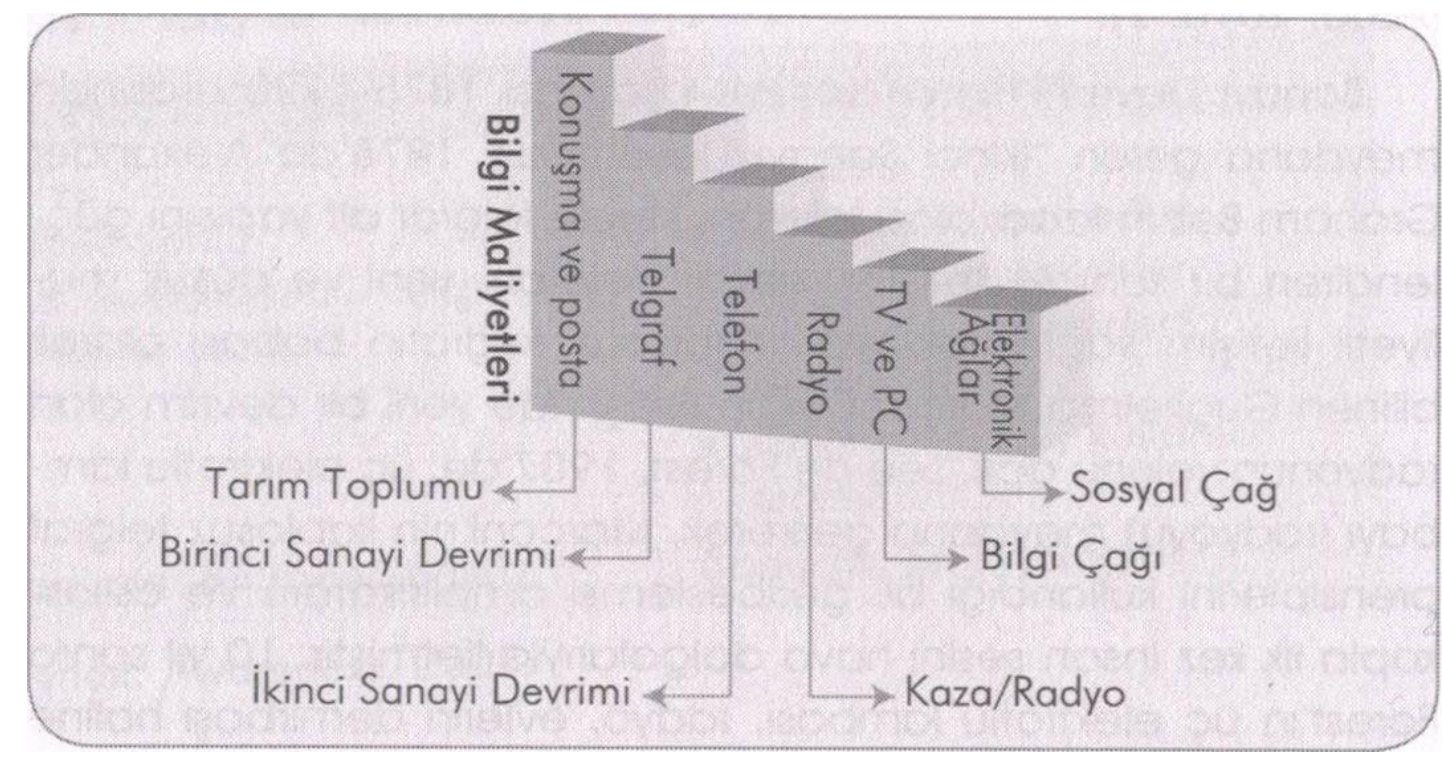

Kaynak: Maria Azua, (2010). The Social factor-Immovate, Ignite and Win through Mass Collaboration and Social Networking, IBM Press: NJ, s.64.

1990'lı yılların bitimine doğru ortaya çıkan çevrimiçi sosyal ağlar, ölçümlü internet uygulamaları olarak hayatımızda yer edinip, bireysel iletişim ve etkileşimin basit hale gelmesine büyük katkı sağlamıştır. Kullanımı sağlayan bireyler şahsi çevrimiçi sosyal ağlarını oluşturup, ağ üstünde kayıtlı olan arkadaşlarının yanı sıra tanımadığı kişilerle de çevrimiçi ağlar sayesinde iletişim kurma imkanına sahip olmuşlardır. Söz konusu çevrimiçi uygulamaların ilklerinden bir tanesi olan

${ }^{1}$ A.C. Newman and J.G. Thomas, Enterprise 2.0 Implementation, Mc-Graw Hill: New York, 2009, s.54
Classmates.com bireylere üniversite veya lise yıllarından eski sınıf arkadaşları ile yeniden iletişim kurma olanağı tanımıştır ${ }^{1}$. Classmates.com, çevrimiçi sosyal ağ oluşturması ile ünlenmiştir². 2002' de, Friendster.com'un yapılmasıyla çevrimiçi ağların gelişim temelleri atılmış olup bahsi geçen ağ Classmates.com tasarımını, kullanıcılara yalnızca şahsi çevrim dışı ağının emsalini çevrimiçi gerçekleştirme imkanının yanı sıra yeni ağları da çevrimiçi yaratma olanağını vererek sosyal ağ anlayışını bir üst kademeye taşımıştır. Kendi

2 Micheal Dulworth, The Connect effect, Publishers, Inc.:CA, 2008, s.102. 
bünyesinde de gelişim göstererek kullanıc profillerinin yanı sıra, bireyin yaşamı hakkında güncel bilgiler elde edilmesini sağlayarak, genel bilgi kaynağı haline gelmiştir. Friendster'in temeli, bloglar aracılığı ile sosyal iletişim olanağını arttırmak ve fotoğraf, bilgi paylaşımını sağlamaktır³. Friendster, üyelerine uygulamaya arkadaşlarını da davet etme imkanı sağlayarak çok fazla kullanıcı kitlesine ulaşmayı başarmıştır ${ }^{4}$. Geliștirilen $3 G$ teknolojisi, tabletler ve akıllı telefonlar iletişim kurma hızını arttırırken, klasik medyanın temel fonksiyonlarına eklenen işbirliği algısı ve yenilikçi anlayış sayesinde dünya sosyal medya ile tanışma imkanını bulmuştur ${ }^{5}$. İki yönlü yapısı, kişilerin şahsi görüşlerine uygun ve istedikleri verileri diğer insanlarla paylaşma imkanı bulması, zaman ve mekan kavramının yarattığı sınırlandırmanın iletişim üzerinden kaldırılmış olması yeni, yani sosyal medyayı klasik medyadan ayıran en önemli özellikler olup. yeni medya

\footnotetext{
${ }^{3}$ Newman and Thomas, a.g.e., s.56.

${ }^{4}$ Carla Mooney, Online Social Networking, Gale, Cengage Learning: Detroit, 2009, s.201.

5 Filiz B. Peltekoğlu, Sosyal Medya
} Akademi, "Sosyal Medya Sosyal Değişim". 2012, İstanbul: Beta Yayıncılık, s.50. 6 Tolga Kara ve Ebru Özgen, Sosyal Medya Akademi, İstanbul: Beta Yayıncılık, 2012, s.102. harici iletişim kanalları için de yarar sağlayıcı bir araçtır 6 .

Sosyal medya, işbirliğine dayanmakta olan, kullanıcının kendisinin oluşturduğu online içeriği belirtmektedir? ${ }^{7}$. Sosyal medya ile ilgili Blossom, her insanın başka insanları ya da grupları kolaylıkla etkilemesini sağlayan ciddi derecede ölçeklenebilir ve erişilebilir iletişim teknolojileri veya teknikleri olarak görüşlerini belirtmektedir, demiştir .

Gelişen ve giderek yaygınlaşan sosyal medya; insanları hem etkileyip hem de kurumlar ve markalar için de değeri gün geçtikçe artan bir yıldız durumuna gelmiştir. 2005'in başı itibariyle sosyal medya; kurumsallaşmış firmalar ve markalar için markalarını ve kurumlarını tanıtacağı, bu yolla daha az maliyetle milyonlara ulaşabileceği vazgeçilmez bir iletişim aracı olmuş ve sosyal medyada bulunmak artık bir zorunluluk haline gelmiştir9.

Sosyal medyanın ve geleneksel medyanın ortak taşıdığı bir karakteristik

\footnotetext{
7 Axel Bruns and Mark Bahnisch, "Social Media: Tools for User Generated Content Social Drivers Behind Growinf Consumer Participation in User-Led Content Generation", State of the Art, Volume 1, March, 2009, s.68

8 John Blossom, Content Nation Surving and Thiriving as Social Media Changes Our Work, Our Lives and Our Future, Wiley Publishing, Inc.: Indiana, 2009, s.23. ${ }^{9}$ Kara ve Özgen, a.g.e., s.103.
} 
nitelik, büyük ya da küçük kitlelere hızlıca ulaşabilmeleridir; örnek gösterecek olursak, bir blog yazısı ve bir televizyon programı kimseye ulaşamayabilir ya da milyonlarca kişiye ulaşabilir. Sosyal medya ve geleneksel medya arasındaki farklardan birkaçını şu şekilde sıralayabiliriz ${ }^{10}$;

\section{Erișim:}

Geleneksel medya ve sosyal medya teknolojileri her bireyin genel bir kitleye erişmesine yardım eder.

\section{Erișilebilirlik:}

Geleneksel medya için üretim yapmak hükümetlerin ve özel şirketlerin sahiplenmesiyle oluşur; sosyal medya herkesçe az ya da sıfır maliyet ile oluşturulabilir.

\section{Kullanılırlık:}

Geleneksel medya üretimi uzmanlık gerektirir. Çoğu sosyal medya için bu uzmanlaşma geçerli değildir ya da birkaç durumda yetenekler tamamiyle değişmiş ve yenidir, yani herkes üretimde bulunabilir.

\section{Yenilik:}

Geleneksel medya iletişimlerinde zaman farkları oluşabilmesinden dolayı (günler, haftalar, hatta aylar) anında etki ve tepkisi olmamaktadır. Sosyal medyadaysa durum tam aksidir. Geleneksel medyada artık sosyal medya uygulamalarına adapte olmakta ve yakın bir tarihte bu farklılığın yok olacağı öngörülmektedir.

\section{Kalıcılık:}

Geleneksel medya oluşturulduktan sonra değiștirilememesinden kaynaklı olarak (bir dergi makalesinin basılması ve dağıtılmasının ardından aynı makale üzerinde değişiklik yapılamaz) problem yaratabilir, sosyal medyada yorumlar, yazılar anında değiştirilebilir.

Başka bir bakış açısıyla olaya bakacak olursak; Geleneksel medyayla sosyal medya 2 noktada ayrışmaktadır. 1.si Sosyal medyada içerik öznel olup bireyler veya kurumlar tarafından oluşturuluyor, geleneksel medyadaysa belli bir yönetimi ve işleyişi olan kurumlar söz konusu; 2 . noktaysa; sosyal medya, geleneksel medyaya göre daha özgür bir ortam sağlarken bir o kadar da kontrolsüz bir ortam sunmaktadır ${ }^{11}$.
“Hastaneler" Özel sayısı, C.10, Ankara, 2012, s.104.

11 Özgen, a.g.m., s.105. 


\subsection{Sosyal Medyanın Toplumsal Etkileri}

Yetişkinlerden ziyade, internet ve sosyal medyayı gençler kullanmaktadır. Önemli bir kısım yetişkin ise ya maddi imkanının olmasına rağmen (bilgi eksikliği nedeniyle) bu araçları kullanamamakta ya da ekonomik imkansızlıklardan dolayı bu dünyadan uzak kalmaktadırlar ${ }^{12}$.

Kullanıcının sosyal medyada bulunan içerikleri oluşturması sebebiyle yaratıcılığın, aykırılığın ve farklılığın önem kazanmasıyla katılım çağı oluştu. Başka bir deyişle bir büyük sanayi kuruluşu niteliğinde üretim tesisi bulunan büyük medya kuruluşlarının hegomanyası kırılarak artık medyanın içeriğini üreten ve medyayı izleyen arasında bulunan katı ayrım ortadan kalktı. Bunun yanında değişim hızı da arttı. İnnovatif olarak yeniliklere öncü olmak insanlar açısından öneme sahip oldu. Derinlemesine bakıldığındaysa gerçeklere değil fikirlere önem verildi, objektif olmanın yerine içten olmak önem kazandı. Yani aslolan ilgi çekerek karşıdakini direkt şekilde etkileme haline geldi. Bundan dolayı insanın fikri veya kendisi bir ticari mal gibi reklama muhtaç bir kisveye

${ }^{12}$ Cihad Çildan ve Mustafa Ertemiz, "Sosyal Medyanın Politik Katılım ve Hareketlerdeki Rolü", Akademik Bilişim, 2012, s.21.

13 Veysel Eren ve Abdullah Aydın, "Sosyal Medyanın Kamuoyu Oluşturmadaki Rolü ve bürünmüştür. Bunun sebebiyse reklam yapma amacının temelinde ne olursa ve ne şekilde olursa olsun ilgi çekme ve tercih edilmeyi sağlamanın yatıyor olmasıdır. Sanal ortamın getirmiş olduğu realiteden uzaklığın esasında insanların birebir veya maddi şekilde karşı karşıya gelememesinden kaynaklandığı bu noktada belirtilmesi gereken en önemli husustur. Yani yüz yüze görüşmeyen anlatımda bulunurken birbirlerinin gözlerine bakmayan insanlar birbirlerine karşı her konuda daha acımasız ve pervasız olmaktadırlar. Sosyal medya tarafından yeni bir ilişkiler ağı ve iletişim jargonunun oluşturulması da bunun bir göstergesidir. Bir müstear (veya diğer bir ifade ile nickname) ismin arkasına saklanmanın vermiş olduğu özgüvenle bireyler muazzam bir ifade özgürlüğüne kavuşmuştur. Dolayısı ile bundan sonra insanlar bilinçaltlarında sıkışmış duygu ve düşünceleri rahat rahat toplumun ya da karşıdakinin değer yargılarını göz önünde bulundurmadan ifade edebilir bir hal almıştır'13.

Esasında sosyal medya kullanımı sırasında içerik şeklinde nitelendirilmekte olan bilgi, fikir ve haber

Muhtemel Riskler". KMÜ Sosyal ve Ekonomik Araştırmalar Dergisi, 16 (Özel Sayı I), 2014, s. 202. 
benzeri şeylerin etkilendiği her bireyin bunu yapma konusunda özgür olduğunu bilmesiyle diğer insanlar ile eşit olduğu düşüncesinde olması söz konusudur (en azından her içerik paylaşan insanla). Insanlarda demokrasi fikrinin oluşabilmesi açısından bu his uygun ortam sağlar. $\mathrm{Bu}$ durum, kişiler tarafından internette öne sürülen düşüncelere, paylaşımlara, tanıyor oldukları kişiler olsun veya olmasın, diğer paylaşımcılar tarafından yapılan yorumlar ve geribildirimler ile bir sosyal etkileşim alanı ve git gide sanal cemiyetler oluşturur. Batı dünyası tarafından sürekli şekilde demokrasinin yaygınlaştırılabilmesi amacıyla teknolojik gelişmelerin pazarlanması, baskıcı rejimlerin internet üzerindeki faaliyetlerinin yalnızca internet sitelerinin kapatılması ya da internet sitelerine erişiminin yasaklanmasından çıkararak, sosyal paylaşım sitelerinin protestocuların takip edilmesinden, kendi propaganda sitelerinin kurulmasına dek olan bir yelpazede pozisyon alınmasına yöneltebilmektedir ${ }^{14}$.

\subsection{Türkiye'de Sosyal Medya}

\section{Kullanımı}

TUIK (2016) ${ }^{15}$ raporuna göre; bilgisayar ve internet kullanım oranları 2016 yılı Nisan ayında 16-74 yaş grubundaki bireylerde sırasıyla $\% 54,9$ ve $\% 61,2$ oldu. $\mathrm{Bu}$ oranlar erkeklerde $\% 64,1$ ve $\% 70,5$ iken, kadınlarda \%45,9 ve \%51,9'dur. Bilgisayar ve internet kullanım oranları, 2015 yilında sırasıyla $\% 54,8$ ve $\% 55,9$ 'du. Türkiye genelinde İnternet erişim imkanına sahip hanelerin oranı 2016 yılı Nisan ayında \%76,3 olup, evden internet erişimi olmayan hanelerin \%59'u bağlanmama nedeni olarak internet kullanımına ihtiyaç duymadıklarını, $\% 29,4$ 'ü interneti, iş, okul, internet kafe gibi başka yerlerde kullandıklarını söyledi. Genişbant internet erişim imkanına sahip hanelerin oranı \%73,1 oldu. Buna göre hanelerin $\% 39,5$ 'i sabit genişbant bağlantı (ADSL, kablolu internet, fiber vb.) ile internete erişim sağlarken, \%65,2'si mobil genişbant bağlantı ile internete erişim sağladı. Internet kullanım amaçları dikkate alındığında, 2016 yılının ilk üç ayında internet kullanan bireylerin \%82,4'ü sosyal medya üzerinde profil oluşturma, mesaj gönderme veya fotoğraf vb. içerik

15 TUIK, 20 Kasim 2016, http://www.tuik.gov.tr/PreHaberBultenler i.do?id=21779

\footnotetext{
${ }^{14}$ Çildan ve Ertemiz, a.g.m., s.21.
} 
paylaşırken, bunu $\% 74,5$ ile paylaşım sitelerinden video izleme, \%69,5 ile online haber, gazete ya da dergi okuma, \%65,9 ile sağlıkla ilgili bilgi arama, \%65,5 ile mal ve hizmetler hakkında bilgi arama ve $\% 63,7$ ile internet üzerinden müzik dinleme (web radyo) takip etmiştir. İnternetin birçok farklı kullanım alanı olduğunu düşünüldüğünde her yaş grubundan bireyin internetten yararlandığını söylemek mümkündür. Türkiye'de 2007'den 2014'e kadar geçen sürede internet erişimi olan hanelerde \%40'a yakın bir artış meydana gelmiştir. Ek olarak 2007-2014 seneleri arasında 1674 yaş grubu kişilerde bilgisayar ve internet kullanımı oranlarında düzenli bir yükseliş saptanmıştır. Ülke çapında internete evden ulaşım imkanına sahip hanelerin oranı, 2016 senesi Nisan ayı itibariyle \%76'ya ulaşmıştır. Bu imkana sahip olmayan hanelerin \%59'u bağlanmama sebebi olarak internet kullanımına ihtiyaç duymadıklarını, \%29,4'ü interneti hane dışı yerlerde kullandıklarını belirtmişlerdir. Yapılan araştırmada 2016 senesi Nisan ayı itibariyle hanelerin \%96,9'unda akıllı telefon ya da cep telefonu mevcut iken, sabit telefona sahip olan ailelerin oranı \%25,6 olarak saptanıştır. Yine 2016 senesinin Nisan ayında hanelerin \%36,4'ünde taşınabilir bilgisayar, \%22,9'unda ise masaüstü bilgisayar bulunurken tablet bilgisayar bulunma oranı \%29,6 olarak saptanmıştır.

2015 yllında \%20,9 olarak ölçülmüş olan internete bağlantısı bulunan televizyona sahip olma oranının, 2016 yılında \%24,6'a ulaştığı saptanmıştır.

\section{Tablo 1: İnternet Kullanımlarının Yașa Göre Oranları 2016}

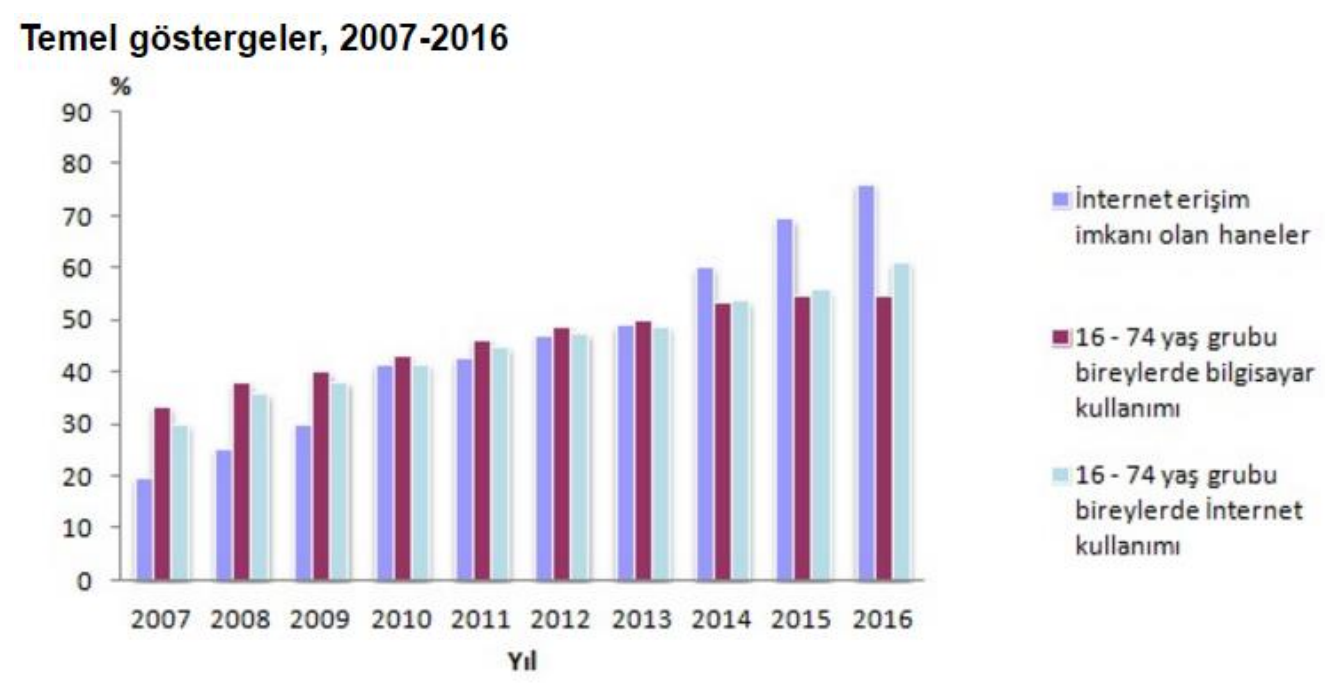

Kaynak: TUiK 20 Kasım 2016, http://www.tuik.gov.tr/PreHaberBultenleri.do?id=21779 
We Are Social (2016)'ın sosyal ve dijital trendlerini ve istatistikleri raporuna göre; Ülkemizde internet kullananların bütün nüfusa oranı $\% 53$ 'tür. Sahte hesaplar da dâhil olmakla birlikte sosyal medya kullanıcılarında \%17lik bir artış meydana gelmiştir. Sosyal medyayı aktif bir biçimde kullananların oranında $\% 10$ artış gözlenirken, ülke genelinde günlük ortalama internette geçirilen süre; kişisel bilgisayarlardan yaklaşık olarak beș saat, saat mobil cihazlardan ise yaklaşık olarak iki saat olarak tespit edilmiştir.

Şekil 2: Türkiye'den sosyal medya bağlantıları

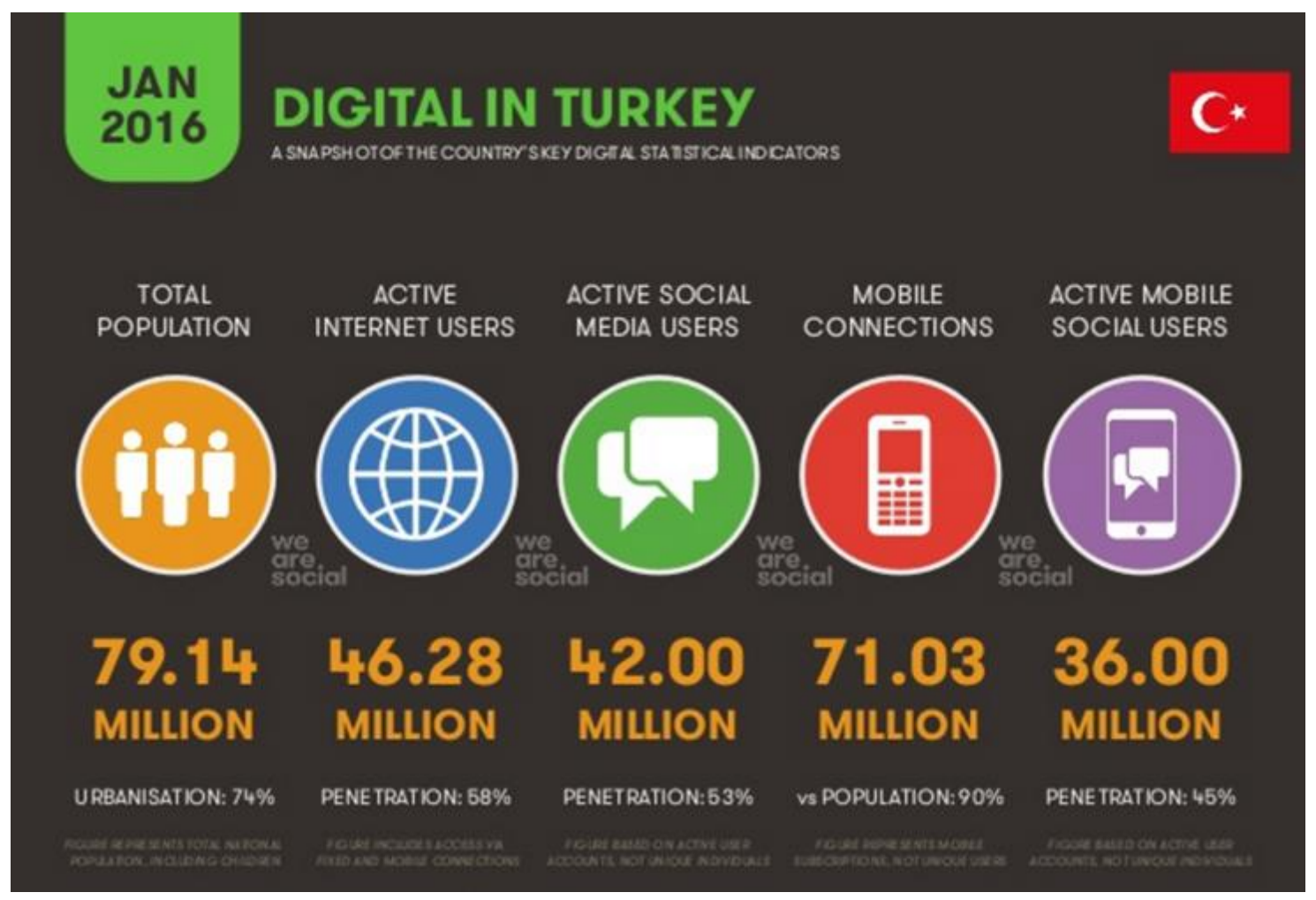

Kaynak: We are social, 20 Kasım 2014, January, http://wearesocial.net/ 
Şekil 3: Türkiye'de Farklı Cihazlarla İnternete Bağlanma

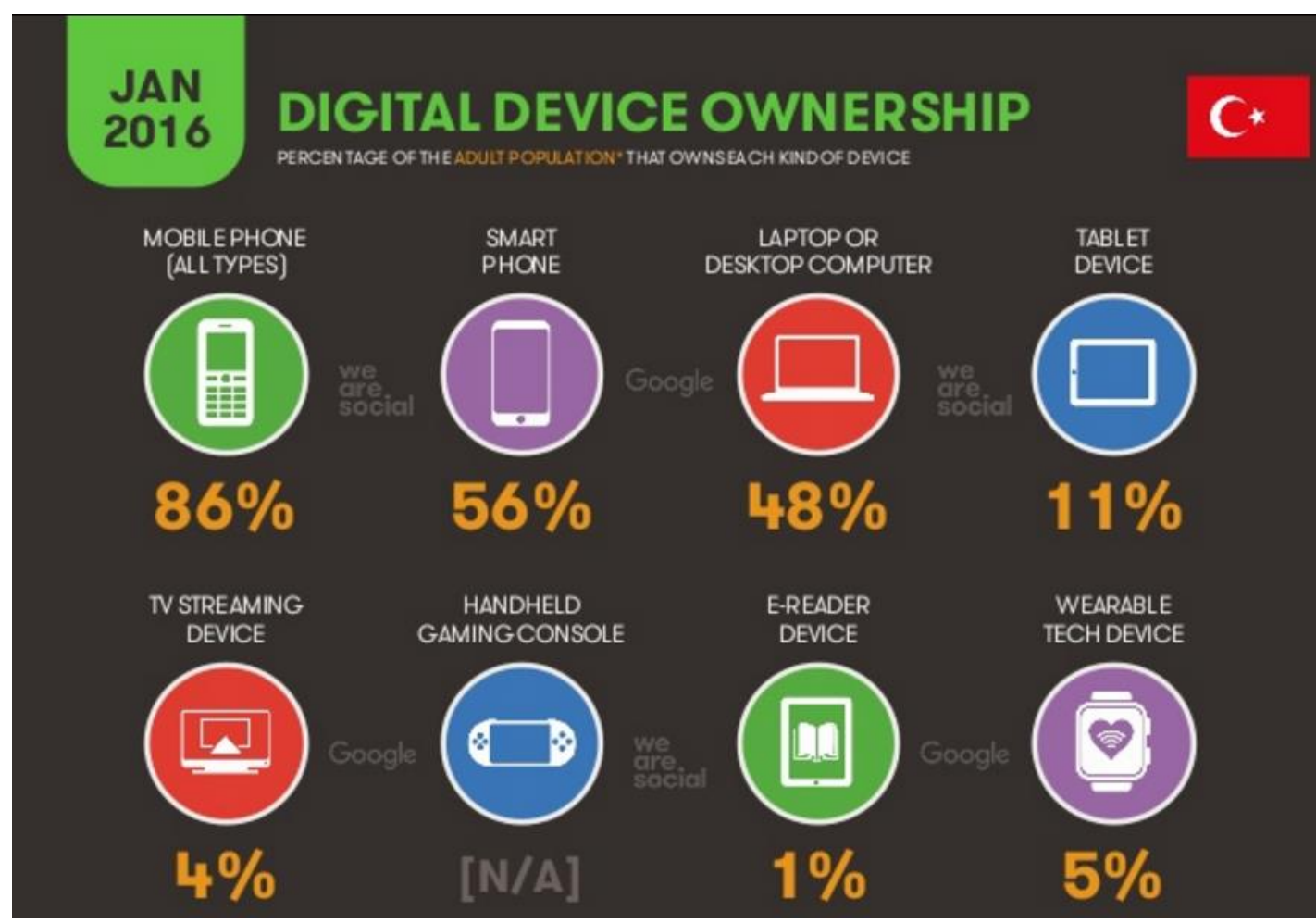

Kaynak: We are social, 20 Kasım 2014, January, http://wearesocial.net/

Şekil 4: Türkiye'de sosyal medya kullanımı

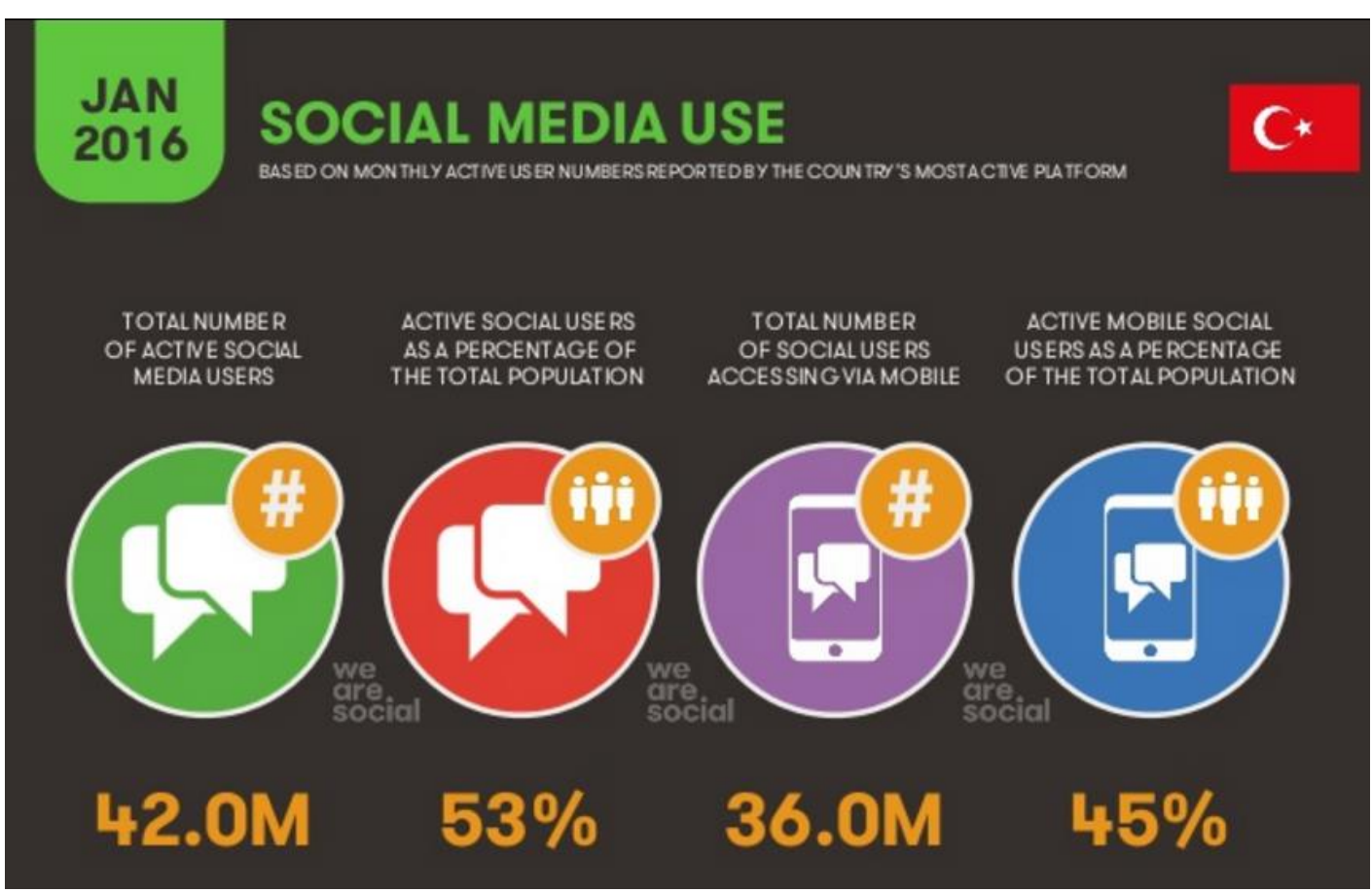

Kaynak: We are social, 20 Kasım 2014, January, http://wearesocial.net/ 


\section{Şekil 5. Türkiye'de En Fazla Kullanılan Sosyal Medya}

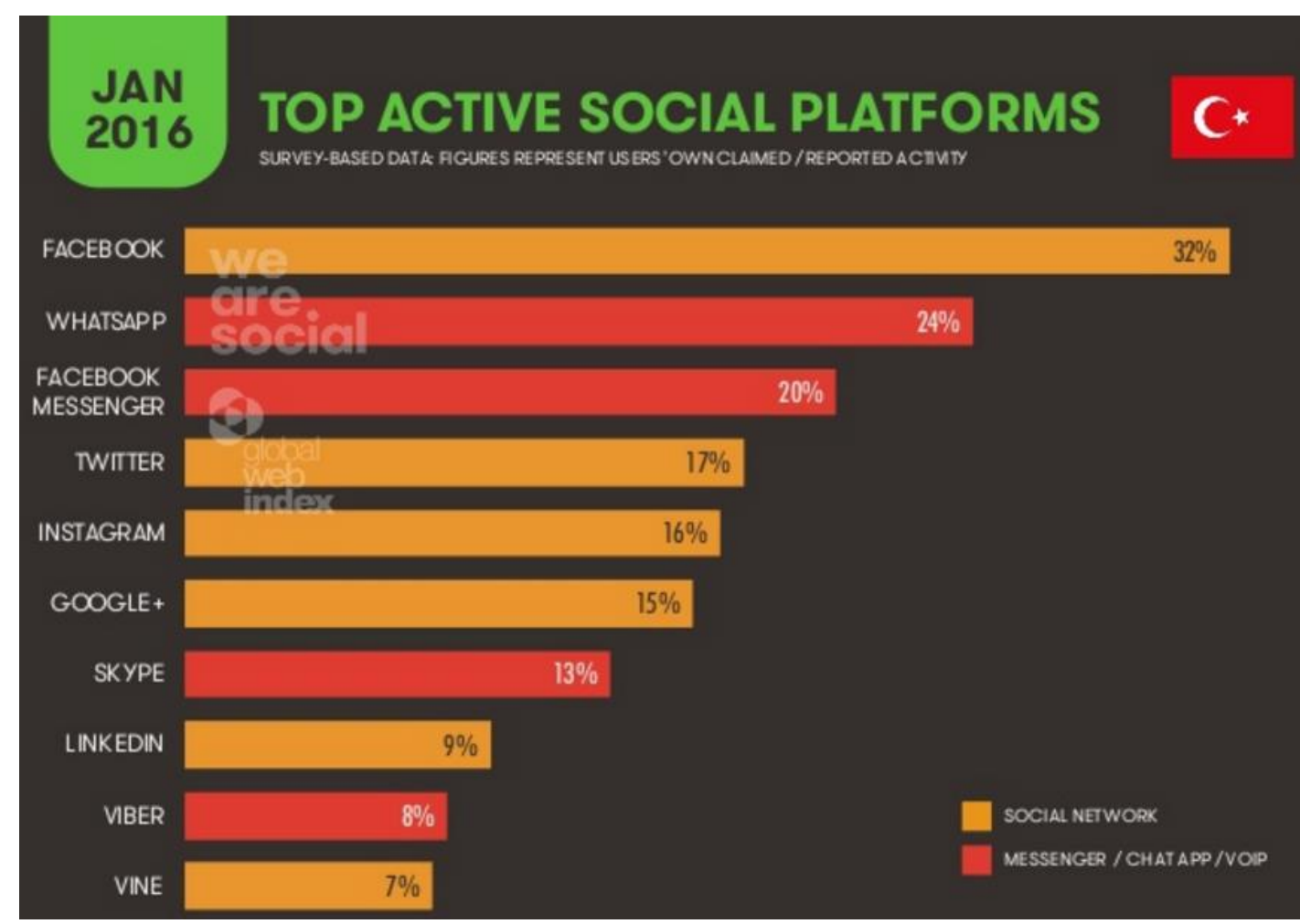

Kaynak: We are social, 20 Kasım 2014, January, http://wearesocial.net/

Internetin haber/gazete okuma amacıyla erkekler tarafından $\% 85$ oranında kullanılırken kadınlar tarafındansa sosyal medya üzerinde vakit geçirme $\% 81$ oranında ve film/ dizi izleme amacı ile $\% 63$ oranında kullanıldığı belirtilmektedir. Erkeklerin daha aktif olduğu diğer iki alanı \%84 ile banka işlemleri ve \%51 ile emlak/otomobil siteleri oluşturmaktayken $\% 69$ ile online alışverişte eşittirler. 2014'te bir araştırma şirketinin yaptığı araştırmaya göre alışveriş siteleri \%65 oranında erkek \%70 oranında kadın olmak üzere takip edilmektedir. Sosyal medya hesaplarının dağılımı \%57 oranında erkek \%60 oranında kadın, \%36 oranında erkek \%38 oranında kadın olmak üzere iş/okulla ilişkili siteler, \%30 oranında erkek \%32 oranında kadın şeklinde hava durumu sayfaları ve \%31 oranında erkek \%27 oranında kadın şeklinde sinema siteleri sayfalarında birbirine yakın oranlardadır. \%75 oranında haber ve $\% 43$ oranında teknoloji erkeklerin kadınlardan önde bulunduğu sayfalardır. \%52 oranında yemek tarifleri ve \%34 oranında müzik ile de kadınların önde olduğu sayfalar belirtilebilir. Bunun yanında kadınların internet alışverişleri içinde giyimde \%71 oranıyla ayakkabıda 
\%57 oranıyla açık ara ile önde olduklarını göstermektedir. Elektronik eşya konusunda \%68 oranıyla, maç/gösteri/konserde \%32 oranıyla (Kadın: \%19) ve çiçek gönderiminde \%41 oranıyla (Kadın: \%28) erkeklerin üstün oldukları görülmektedir. Kadınların ve erkeklerinse kitap/dergi, hediyelik eşya, ev eşyası, yemek siparişi ve telefon kontör yükleme kategorilerinde eşit oldukları saptanmaktadır'.

2014'te Türkiye'de Adecco'nun yaptığı araştırmalar, sosyal medyanın iş arama amacıyla iş arayanlar tarafından \%64 oranında kullanıldığı göstermektedir. Sosyal ağ sitelerinden en fazla (\%53) Linkedın sitesi profesyonel amaçlı iş arayanlar tarafından kullanılmaktadır. Türkiye'de kadınların ve erkeklerin sosyal medya kullanım oranlarının genel kullanım ya da iş arama oranlarına bakıldığı zaman kadınların az bir farkla olsa dahi sosyal medya kullanımında erkeklerden etkin olduklarını görmek mümkündür (\%99 vs \%97 ve \%74 vs 70 ). 1965 ve 1980 (\%99) döneminde doğmuş olanlar bu araçları en fazla kullanan grubu oluşturmaktadır. Bu oranlara nispet ile genç iş arayanlardan (33 yaş

1 Fikrimühim Araştırma Şirketi, 15 Kasım 2016, https://www.fikrimuhim.com/Binary/ Images/Upload/internetarastirmasi/FM_DAtu\%CC\%88mu\%CC\%88.pdf. altı) \%97 kadarının en azından sosyal ağlardan birini iş bulma amacı ile düzenli olarak kullandıkları görülür. İnterneti bu amaç ile kullanırken eğitim seviyesi de önem kazanmaktadır. Zira iş bulma amacıyla sosyal medya kullanımı orta dereceli okul mezunu olanların arasında yüksek eğitim seviyelerine ulaşma ile önemli derecede artmaktadır. Kullanım bakımından mezuniyet seviyelerinin ötesindeki eğitim seviyeleri genellikle önemsizdir².

\section{KURUMSAL ITIBAAR OLUŞTURMA}

Saygınlık ya da diğer adıyla itibar; insanların bir birey ya da bir konu ile ilgili besledikleri görüşleri, söz konusu bireyin ya da konunun geçmiş dönem tutumlarına veya kişiliğine bakarak diğerlerinin takdirini ne ölçüde kazandığı ve ne kadar kabul gördüğüyle alakalı olan bir kavramdır. 1990'lı senelerden sonra araştırmacılar ve akademisyenler tarafından yapılan saygınlık kavramına yönelik çalışmalar kurumsal çalışmalar, pazarlama, iletişim, stratejik yönetim ve

2 Adecco, Rapor-2014, Türkiye. 15 Kasım 2016, http://www.adecco.com.tr/trTR/Documents/Sosyal\%20medya\%20anke ti\%20T\%C3\%BCrkiye\%20raporu_.pdf 
pazarlama benzeri sektörlerde hızlı bir ilerleme kat etmiştir³.

Belirli bir fabrikaya duyulan inanç, söz konusu fabrikayla kurulan iletişim ve fabrikanın sunduğu hizmet ve ürünler ile fabrikanın nitelik ve yeteneği ile ilgili veri ve bilgilerden meydana gelir. Bu noktada inanç sahibinin bilgi ve tecrübeleri saygınlığın yeniden kazanılmasını sağlayacak biçimde, diğer insanların söz konusu fabrikayla ilgili fikirlerini meydana getirir ${ }^{4}$. Birey, fabrikanın sunmuş olduğu hizmet ve mallarından memnun kaldığı ölçüde fabrika ile mevcut iletişimini doğru orantılı olarak arttırır ${ }^{5}$. Kuruluşlar yarıştığı, kendine rakip gördüğü firmaların nazarında düşük seviyeli bir saygınlık edindiğinde rekabetçi tutumların etkisi altında riski, saygınlığı yüksek olan kuruluşların aynı durumda karşı karşıya kalacağı riskten daha fazladır ${ }^{6}$.

Kuruluşun saygınlığı, geçmiş dönemlerde sergilediği tutumları ve farklı hissedarlar

3 Greeme Martin ve Susan Hetrick, Corporate Reputations,Branding and People Management: A Strategic Approach to HR. Burlington: ButterworthHeineman Publications, 2006, s.21.

${ }^{4}$ Grahame Dowling, "Measuring Corporate İmages: A Review of Alternative Approaches", Journal of Business Research, 17(1), 1988, s.284.

5 Mehmet E. Okur, "Kurumsal Saygınlık Yönetimi", Marmara Üniversitesi Sosyal Bilimler Enstitüsü Hakemli Dergisi, 7(26), 2006, s.145. üstünde değer sağlayan etkiler bırakma kabiliyeti neticelerinin kolektif olarak tanımlanmasıdır. Söz konusu durumların, harici ve dahili hissedarların değişiklik gösterebilen tavırlarını derecelendirmekte; kurumsal çevreleri içermesinin yanı sıra rekabete dayalı bir tutum sergilemektedir? Kuruluş saygınlığını; genellikle hissedarların kurumun türü, sorumluluk ve görevlerini yerine getiriş biçimi, hissedar beklentilerinin sağlanış şekli ve çevreye sağladığı uyuma dair incelemelerinin uzun süreli kombinasyonudur ${ }^{8}$.

Itibar sağlama ve elde edilen itibarı sürdürme elde etmesi oldukça zor, kaybetmesi ise bir o kadar kolay bir durumdur. Benzer olarak itibarın bir rekabet üstünlüğü olarak algılanması uzun sürede, itibarı kaybetmenin etkileriyse orta ve kısa dönemde

6 Gary Davies, Rosa Chun, Rui V. Silvave Stuart P. Poper, Corporate Reputation and Competitiveness. New York: Routledge, 2003, s.66.

7 Charles Fombrun, "Indices Of Corporate Reputation: An Analysis of Media Rankings and Social Monitors Ratings, Corporate Reputation Review, 1(4), 1997, s.330.

8 Cretu E. Anca ve Brodie Roderick, "The Influence of Brand Image and Company Reputation Where Manufacturers Market to Small Firms: A Customer Value Perspective", Industrial Marketing Journal, 36, 2007, s.136. 
gözlenmektedir'9. Cravens ve Oliver saygınlık terimini, ekonomik krizin baş gösterdiği dönemlerde kurumun etkilenmesini önleye, kurumun hissedarları ya da toplum üzerinde bıraktığı etki olarak tanımlamışlardır. Meydana gelen Tylenol krizinden sonra Johnson ve Johnson üst yönetim kadrosu üyelerinden James Burke "Biz 90 senelik itibarımızdan nakit sağladık" ifadesini kullanmıştır ${ }^{10}$.

Belirtildiği şekliyle ele alındığında kuruluş saygınlığı ve kriz yönetimi arasında bağlantılı bir ilişki olup Laczniak ve arkadaşlarının (2006) ${ }^{11} \quad$ yürüttükleri çalışmada işletme mallarında ortaya çıkan hatalardan kaynaklı söz konusu işletmenin suçlu bulunması arasında bir ilişki olduğu belirtilmiştir. Yapılan araştırmada örnek olarak iki grup seçilmiş olup, gruplardan ilki, tanınan ve yüksek marka değerine sahip bir işletme olan Compaq bilgisayarında meydana gelen sorunlar hususunda bilgilendirilirken; ikincisi tanınırlığı daha az olan Everex bilgisayarlara yönelik

${ }^{9}$ Okur, a.g.m., s.144.

${ }_{10}$ Kares S. Cravens ve Elizabeth G. Oliver, "Employees: The Key Link to Corporate Reputation Management", Business Horizons. 49(4), 2006, s.295.

11 R.N. Laczniak, T.E. Decarlo, ve S.N. Ramaswami, "Consumers' Response to Negative Word-Of-Mouth Communication: An Attribution Theory Perspective", Journal of Consumer Psychology, 11(1), 2006, s.62. sorunlar hakkında bilgilendirilmiştir. Compaq bilgisayar hakkında bilgi edinen bireyler sorunların sebebi olarak kullanıcı hatalarını gösterirken, daha az bilinen Everex bilgisayarın problemleri hakkında yorum yapan kişiler hatalı olarak markayı bulmuşlardır ${ }^{12}$.

Sağlam bir şekilde oluşturulmuş kuruluş saygınlığı rekabet ortamında önemli bir avantaj sağlarken, sağlam olmayan saygınlık işletmenin rakipleri karşısında başarı elde etmesini engelleyen bir faktör olabilir. Bowd (2006)'a göre, negatif yönlü bir saygınlığın kurumlar üzerindeki etkileri şunlardır ${ }^{13}$ :

- Personellerin yeni öneriler getirememesi,

- Sürekli personel değişimi,

- Satıcı güvenirliliğinin düşük olması,

- Önemli müșterilerin kaybedilmesi,

- Hisse senetleri değerlerinin hızlı bir şekilde düşüşe geçmesi,

12 Daniel Laufer ve Timothy Coombs, "How Should a Company Respond to a Product Harm Crisis? The Role of Corporate Reputation and Consumer Based Cues", Business Horizons, 49(5), 2006, s.381.

13 Ryan Bowd ve L. Bowd, Assessing A Financial Value For A Corporate Entity's Reputation; A Proposed Formula", Research Institute for Business and Management, 2006. 
- Devlet ilişkilerinin zayıf olması,

- Kurum

görüșlerinin

gazeteciler tarafından oldukça nadir alınması,

- Söz konusu kurumun sektör çapında referans olarak gösterilmemesidir.

Güçlü bir kurumsal saygınlık, başarıyla gerçekleştirilmiş kurumsal saygınlık yönetimine dayanmaktadır ${ }^{14}$. Saygınlık yönetimi; işletmenin en önemli değeri olan kurumsal saygınlık kavramının varlığını sürdürmeyi ve ilerletmeyi hedefleyen öğelerin yönetimidir ${ }^{15}$.

Davies ve ark. (2003)' na göre saygınlık yönetimi şartları şunlardır ${ }^{16}$ :

- Saygınlık açık bir şekilde yansıtılmalıdır,

- Kilit hissedarlar, söz konusu hissedarların beklentileri ve hassas oldukları noktalar net bir şekilde bilinmelidir,

- İşletme tutumlarına dair verilecek kararlarda bilgi, gerçeğe uygun bir biçimde kullanılmalı ve söz konusu

14 Gary H. Jones, Beth H. Jones ve Philiph Little, Reputation as Reservoir: The Value of Corporate Goodwill as a Buffer Against Loss in Times of Economic Crisis. Wester California University, 2007, s.26.

15 Korn Campiranon. Managing Reputation in Event Planning Companies, 2007, 15 kararlarda işletmenin var oluş sebepleri, amaçları ve marka değerleri düşünülmelidir,

- Söz konusu kararların hayata geçirilmesinde titiz davranılmalıdır,

- İşletme bünyesinde gelişimi sağlanmış ya da yeni olarak düzenlenmiş konular hakkında ortaya atılabilecek iddialara karşı hazırlıklı olunmalı ve profesyonel bir şekilde geri dönüş sağlanmalıdır,

- Medya soruları ve saldırgan ya da baskıcı tavırlara geri dönüş hızlı bir biçimde yapılmalı, bu konuda hassas olunmalıdır.

Bilinen dergilerden olan PRWeek tarafından gerçekleştirilen bir ankette üst düzey şirket CEO’larının \%75’i şahsi işletmelerinin saygınlığına yönelik tehditlere maruz kaldıklarını düşündüklerini dile getirmişlerdir. Kurumsal itibarın etkili oluşunun nedenleri ve bu etkinin nasıl ölçülebileceği yapılan araştırmalarca işletme saygınlığının mevcut piyasada bir işletmeye birçok konuda çeşitli avantajlar sağladığı ortaya konulmuştur ${ }^{17},{ }^{18}$.

Kasim 2016, http://eprint.uq.edu.au/ archive/ 00004619/01/.

16 Davies vd., a.g.e., s.104.

17 Ingemar Dierickx ve Karel Cool, "Asset Stock Accumulation and Sustainability of Competitive Advantage", Management Science, 35, 1989, s.1506.

${ }^{18}$ Louis Capozzi, "Corporate Reputation: Our Role in Sustaining and Building A Valuable 
İşletme saygınlığının etkisini ölçmek için dünya çapında değişik çalışmalar ve deneyler yapılmıştır. Örnek olarak, Çin'de işletmeler arası hizmet sunan üç firmanın üç yüz elli bir müşterisiyle yürütülen deneysel çalışmada işletme saygınlığı bağımsız; müşteri güveni, müşteri özdeşleşmesi, müşteri bağlılığı, satın alma niyeti ve prestij fiyatlandırma bağımlı değişken olarak kullanılmıştır. Yapılan çalışmanın neticesinde pozitif saygınlığı bulunan işletmelerin müşteriler bünyesindeki özdeşleşme ve güven sağlama hususunda kazanç elde ettikleri ve bunun müşteri bağlılığını pozitif yönde etkilediği ortaya konulmuştur. Söz konusu kavramlarla prestij ve satın alma isteğiyle fiyat belirleme arasında aracı görevi görmektedir ${ }^{19}$.

Isssletme saygınlığıyla alakalı gerçekleştirilen diğer bir deneysel araştırma Hansen ve ark. (2008) tarafından yapılmış olup alıcıların finansal değer algısını meydana getiren öğeleri belirlemek hedefiyle, Avrupa'daki bir telefon şirketinin 264 müşterisiyle bir anket çalışması gerçekleştirilmiştir.

Asset", Journal of Advertising Research, 45(3), 2005, s.290.

19 Hean T. Keh ve Yi Xie, "Corporate Reputation and Customer Behavioral Intentions: The Roles of Trust, Identification and Commitment", Industrial Marketing Management, 38(7), 2009, s.736.

${ }^{20}$ Havard Hansen, Bendik M. Samuelsen ve Pal R. Silseth, "Customer Perceived Value in
Değişkenlerin tümünün kaynağı harici olarak kabul edilen, doğrulayıcı faktör analizi ölçüm modelinden yararlanılan çalışma neticesinde işletme saygınlığı, veri paylaşımı ve esnekliğin alıcı değer algısı üzerinde etkili olan etmenler; ağızdan ağza pazarlamayla seçenekleri arttırmanın ise alıcı değer algısından etkilenen etmenler olduğu belirlenmiştir ${ }^{20}$.

Bir işletmenin hissedarları tarafından nasıl algılandığı önemli bir husus olup, işletme saygınlığını kavramak için üzerinde durulması gereken bir diğer konu da hissedarlardır. Bu sebepten dolayı işletmelerin mevcut saygınlıklarını devam ettirebilmeleri ve mevcut saygınlığı geliştirebilmeleri için, hissedarları olan kişiler ya da kurumlar ve söz konusu kişi ya da kurumların gözünde işletmenin bulunduğu konum büyük önem taşımaktadır. İşletmenin saygın bir konumda bulunması ve sağlanan saygınlığın muhafazasının yapılması için aşağıda verilen soruların cevaplandırılması gerekmektedir²1:

B-T-B Service Relationships: Investigating The Importance of Corporate Reputation", Industrial Marketing Management, 37, 2008, s.209.

${ }^{21}$ Halil Saylı ve Özlem Y. Uğurlu, "Kurumsal İtibar ve Yönetsel Etik İlişkisinin Analizine Yönelik Bir Değerlendirme", Süleyman Demirel Üniv. İïBF Dergisi, Cilt 12, Sayı 3, 2007, s.80. 
- Nasıl Bir Saygınlık; işletmeler, değişik nitelikler, tutumlar ve neticeler meydana getirerek saygın bir konuma ulaşabilirler.

- Kim İçin Saygınlık; işletme saygınlığı konusunda toplum algısı büyük önem taşımaktadır. Fakat söz konusu algı belirlenmesinde önem taşıyan kitle kurum tarafından belirlenmelidir. Bazı işletmeler için personelleri önem taşırken başka bir kurum için bu konumda bulunan kesim müşteriler olabilmektedir. Önem taşıyan grubun belirlenmesi saygınlık amacını da belirlemektedir.

- Hangi Amaç için Saygınlık; müşteri bağlılığı, yetenekli personellere sahip olma, uzun süreli ekonomik performans ve hissedar değeri söz konusu hedeflerdendir.

\section{SOSYAL MEDYA ARACILIĞI ILE}

\section{KURUMSAL ITIBAR OLUŞTURMA}

Yeni medya olarak tanımlayabileceğimiz sosyal medya araçlarının en yenilikçi yanlarından biri, kullanıcıların arzu, beğeni ve beklentilerini ortaya koyan ve önemseyen bir anlayışa sahip olması olup yeni medyayı diğerlerinden farklı kılan bu yenilikçi nitelik, kullanıcıların görüşlerini aktarmasına, deneyimlerini paylaş-

22 Tolga Kara, "Sosyal Medya Üzerinde Yeni Nesil Pazarlama ve Türkiye Bilgi \& İletişim Hizmetleri Endüstrisinde Sosyal Ağların Kullanımına Yönelik Bir Araştırma", Global malarına imkan sağlamış, etkileşim sayesinde de bu yorumlar artış, göstererek kitlesel bir beğeni meydana getirilmiştir $^{22}$. Bu bağlamda işletmeler daha önce belirtilen Facebook, Twitter, Instagram, Pinterest benzeri yeni medya ağlarını kullanarak alıcılarıyla direkt olarak etkileşimde bulunma imkanına sahip olmaktadır. Örnek olarak, Facebook üzerinden işletme sayfası açılarak şahsi sayfasını beğenen tüketicilere hizmet ve ürünleriyle ilgili bilgi sunmaktadırlar. Benzer şekilde diğer popüler sosyal medya ağları ile de farklı kitlelere ulaşmak ve ürün, hizmet tanıtımı yapmak hatta tüketici şikayet ve isteklerine yanıt vermek mümkün olmaktadır ${ }^{23}$.

İnsanlar kullandıkları ürünleri, yaşadıkları durumları beklentisiz olarak diğer bireylere tavsiye ederler. “Kesinlikle denenmeli" tarzında yapılan olumlu yorum; "asla denemeyin", "asla yapmayın" tarzı olumsuz bir hale de gelebilmekte olup, yeni medyanın etkisini arttırmaya devam ettiği süreçte işletmelerin bu platformdan olumlu görüş alabilmeleri için çaba sarf etmeleri gerekmektedir. Hizmet alanında başarı sağlamanın sırrı olarak değerlendirilen

Media Journal Turkish Edition, Cilt 2, Sayı 4, 2012, s.106.

23 Salim Kadıbeşegil, İtibar Yönetimi, MediaCat Kitapları, İstanbul, 2012, s.58. 
bir birey tarafından bașkalarına aktarımı sağlanan reklamın dünya çapında zaman ve mekan sınırlandırmalarına takılmadan yayılan bir ortamda sağlayacağı başarının oldukça yüksek olabileceği açıkça görülmektedir ${ }^{24}$. Söz konusu etkinliklerin ekonomik değerlerinin oldukça düşük hatta herhangi bir maliyet gerektirmemesi, yeni medya kavramı işletme saygınlığı sağlama ve arttırmaya yönelik stratejilerinin bir numaralı gündem maddesi haline getirmektedir ${ }^{25}$. Yeni medyayla beraber saygınlık sağlama sürecinde kontrol büyük ölçüde müşteride olup içerik tüm kullanıcılara aittir ve sıradan kullanıcılar, etkisiz gözlemciler olmaktan çıkarak yorum ve tavsiyelerde bulunan, ürün ya da hizmetleri destekleme ya da desteklememe yoluna giderek kamuoyu oluşumuna katkıda bulunun insanlar haline gelmektedirler ${ }^{26}$. Buna bağlı olarak işletmelerin saygınlığı, sosyal medyada belirtilen bir düşüncenin olumlu itibarı olumsuz yapabilme gücü ile sürekli bir risk altında olmaktadır. Saygınlıkla alakalı riskler, evrensel medyayla alakalı bilgi ve iletişim teknolojilerinin hızla gelişimini

${ }^{24}$ Kadıbeşgil, a.g.e., s.59.

25 Ali F. Aydın, "Kurumsal İtibar Açısından Sosyal Medyaya İlişkin Bir Değerlendirme", Karadeniz Teknik Üniversitesi İletişim Araştırmaları Dergisi, sayı:9, 2014, s.10. sağlamaktadır. İşletmelerin yeni medya ile bilgi aktarımı hususunda zaman ve mekan sınırları ortadan kalkmaktadır. Yeni medya, işletme saygınlığını olumlu ya da olumsuz etkileyebilecek güce sahip olup bu durumun nedenleri şu şekilde sıralanabilmektedir²

- Kurumla hissedarlar arasında zaman ve mekan sınırlarının ortadan kalkması,

- Yeni medyada işletmenin şasi bilgilerini içermesi ve bu bilgilere ulaşabilirliğin oldukça basit olması,

- Yeni medyada olumsuz görüşlerin hızlı bir biçimde yayılması ve kolay bulunabilmesi,

- Yeni medyada kişilerin kullanıcı adlarıla var olabilmeleri ya da yasal yaptırımların farkında olmamaları sebebiyle değişik etkinliklere girişebilmeleri,

- İşletmeden memnun olanların yeni medyada işletmeyi bir karşılık beklemeden savunmaları,

- Bireylerin klasik medyadan daha çok ortak özellik barındırdıkları diğer insanlara güven duymaları,
${ }^{26}$ Akar, a.g.e., s.26

27 Gamze Er, Sanal Ortamda İtibar Yönetimi, Cinius Yayınları, İstanbul, 2008, ss.78-79. 
- Yeni medyanın işletme saygısını arttırıcı çalışmalar yapması için ortam sunması.

Sosyal medyanın işletme saygınlığı yaratma konusunda Zenelaj (2014) tarafından gerçekleştirilen araştırmada saygınlık yönetmenin önemi üzerinde de durulmuştur. Yapılan etken analizi neticesinde yirmi sorudan meydana gelen kurumsal saygınlık ölçeğinin ankete katılan kullanıcılar tarafından 3 alt boyutta algılandığı ortaya konmuştur. Gerçekleștirilen regresyon analizi neticesinde yeni medya kullanımı kurumsal saygınlık algısı değişkenini açıklama oranı yaklaşık olarak \% 42 olarak bulunmuş olup, bu oranın yeni medya ağlarının kurumsal saygınlık yönetiminde etkili olduğunu ortaya koymaktadır ${ }^{28}$.

Zenelaj'ın yapmış olduğu araştırması sonucunda elde edilen verilere göre aşağıdaki öneriler verilmektedir ${ }^{29}$ :

- Kurumlar, genel stratejisini meydana getirirken yeni medya ağlarını göz ardı etmemelidir. Büyük işletmeler “Kurumsal İtibar Müdürü” olarak bir pozisyona sahip olmalıdır. Küçük ve orta çaplı kurumlardaysa işletme saygıınlığı müdürü pozisyonu oluşturma olanağı

28 Besjon Zenelaj, "Pazarlama Stratejisi Olarak Sosyal Medya İletişimi İle Kurumsal İtibarı Oluşturmak: İletişim Sektöründe Bir Araştırma", (Yüksek Lisans Tezi) T.C. Selçuk olmayabilir. Bu sebepten dolayı işletme saygınlık yönetimi üst düzey yöneticilerin üzerinde durması gereken kilit bir konu olarak algılanmalıdır.

- Kurumlar, yeni medya ağlarından sorumlu olacak personellerine eğitim sağlamalıdır. Yeni medya araçlarında yapılan cevaplar kurum misyon ve değerlerine aykırı olmamalıdır. En önemli konuda yanıltıcı bilgiler barındırılmamalıdır.

- Kurumlar müşteri hizmetlerinde yeni medya ağlarından daha fazla faydalanmalıdır.

- GSM operatörleri kampanyaları yaymak için SMS yöntemini oldukça sık kullanmaktadırlar. Akıllı cep telefonların yaygın bir hal almasıyla beraber söz konusu strateji daha ileri seviyeye ulaştırılabilir. GSM operatörleri akıllı cep telefonu uygulamaları sunarak kullanımını teşvik edebilirler. Söz konusu uygulamaların kullanıcılara ekstra MB internet ya da paralı bazı diğer uygulamaları hediye edebilir.

İşletme saygınlığını geliştirmeye ve saygınlık risklerini ortadan kaldırmaya veya minimum düzeye indirmeye yönelik yeni medya stratejilerinin belirlenmesi gerekmektedir. Söz konusu noktada yeni

Üniversitesi Sosyal Bilimler Enstitüsü, Konya, 2014, s.170.

${ }^{29}$ Zenelaj,a.g.t., ss.170-171. 
medya etkinliklerinin bir plana bağlanarak yeni bireylere ulaşma ve kurum saygıınlığını çevrimiçi ortamlarda artırmak oldukça önemlidir. Yeni medyanın avantaj ve dezavantajlarını göz önünde bulundurmak yoluyla söz konusu ortamın sunduğu fırsatları incelemek ve buna göre gerçekleştirilecek etkinlikleri belirlemek gerekmektedir. Başarılı bir biçimde olumlu itibar sağlandığında, söz konusu işletmeyi destekleyen insanların bu tarz tehditler durumunda devreye girmesi kuvvetle muhtemel olup bazı durumlarda işletme yöneticilerini kendilerini savunmaları yerine bu işi savunucu topluluğa bırakması daha iyi olmaktadır ${ }^{30}$.

İşletmenin güvenilirliğini sağlam bir hale getirmek için devamının sağlanmasına imkan tanıyacak iki kavram "takip" ve "ölçüm" dür. Yeni medya takibi; çevrimiçi ağlarda bir marka, birey ya da kurum hakkında söylenenlerin takip edilmesidir ${ }^{31}$. İşletmeler, bu tür ortamları takip etmenin yanı sıra platformlara katılarak etkinliklerini arttırmaktadır. Çevrimiçi ortamda saygınlığın izlenmesi ve korunmasını gerçekleştirmek için yapılması gereken arama motorlarında ve yeni paylaşım ağlarında işletme veya

\footnotetext{
${ }^{30}$ Er, a.g.m., s.80.
}

${ }^{31}$ Aydın, a.g.m., s.12. markayla alakalı bütün kilit kelimelerin düzenli takibinin sağlanması, işletme internet sayfası ve yeni medya araçları benzeri platformlarda hedef topluluklara sistematik ve doğru bilgi alışverişinin sağlanmasıdır ${ }^{32}$ (Güçdemir, 2012: 103104).

İşletme saygınlığı ve itibarı bakımından yeni medya üzerindeki bu takip ve ölçüm ile beraber yeni medyanın da etkin bir biçimde yönetilmesi gerekmektedir. Söz konusu kapsamda ERA Research \& Consultancy ve Bersay Iletişim Danışmanlığı işbirliğiyle yapılan Türkiye' nin ilk yeni medya trendleri çalışması, pazarlama ve iletişim yöneticilerinin yeni medya kavramını ön plana çıkarması bakımından önem taşımaktadır. Ülkemizde etkinliklerine devam eden 65 firmanın 75 yöneticisinin katılımıyla gerçekleştirilen çalışma, çevrimiçi olarak 2010 yılının Mart ayında yapılmıştır. Yöneticilerin \%95'inin iyi bir yeni medya yönetimi sağlanmadığı sürece işletme saygınlığının kaybedileceğini düşündüğü belirlenmiştir. Diğer analiz sonuçlarıysa aşağıda verilmektedir ${ }^{33}$;

- Yöneticilerin \%80' i Facebook'a üye, \%48'i ise aktif olarak Facebook kullanıyor. Facebook'tan sonra

32 Yeşim Güçdemir, Sanal Ortamda İletişim-Bir Halkla İlişkiler Perspektifi, Derin Yayınları, İstanbul, 2012, ss.103-104. ${ }^{33} \mathrm{http}$ ://www.kigem.com, 10 Kasım 2016. 
kullanımın en yüksek olduğu ağlar Linked-in ve Twitter. Linked-in'e üye olanların oranı \%60; Twitter'a üye olanların sayısı ise \% 54 .

- Pazarlama ve iletişim yöneticilerinin çoğunluğu sosyal medyanın kurumların dış ilişkilerini olumlu yönde etkilediğini düşünüyor. Olumlu bulma oranı kurum içi ilişkiler için ise $\% 52$. Öte yandan, bireylerin kişisel ilişkileri açısından da çoğunluğun sosyal medyayı olumlu bulduğu görülüyor. Bununla birlikte beşte birlik bir kesim sosyal medyanın kişisel ilişkileri olumsuz etkilediği görüşündedir.

- Katılımcıların \%94' ü sosyal medyanın ürün ve hizmetlere ilişkin tüketici görüşleri üzerinde etkili olduğu fikrine katılıyor. Sosyal medyanın her şirket için uygun ve kullanılabilir bir alan olduğu fikrine katılım ise $\% 52$ olarak belirlenmiştir.

- Sosyal medya yöntemlerinin pazarlama ve iletişimde kullanım oranı \& 47 olup çalışmaya katılan yöneticilerin yarısı halen faaliyetlerinde sosyal medya yöntemlerini kullanırken kısa vadede kullanmayı düşünenlerin oranı \%26' dır.

- Sosyal medyayı kullananlar arasında bu aktivitelerin etkinliğini ölçümlediğini belirtenler ise \% 66 oranındadır.
- Bu yıl en yüksek bütçe artışı sosyal medya ile çevrimiçi reklam ve iletişim için öngörülüyor. Araştırmada hem sosyal medya hem de firmalarının çevrimiçi reklam ve iletişim bütçelerinin 2010 senesinde artacağını belirten yöneticiler \% 37 ile en yüksek orana sahiptir. Çalıșmaya katılan pazarlama ve iletişim yöneticilerinin çoğunluğu sosyal medya üzerinden yapılan iletişimin, marka tavsiye düzeyi, marka farkındalığı yaratma ve ürün ya da hizmet hakkında bilgilendirme gibi iş sonuçları üzerinde etkili olduğunu düşünüyor. Pazar payını artırma üzerinde etkili olduğunu düşünenlerin oranının ise daha düşük olduğu görülmektedir.

Yapılan araştırma neticelerinde de görüldüğü üzere, yeni medya üzerinde durulması gereken etkili bir güç haline gelmiştir. $\mathrm{Bu}$ bağlamda işletme idarecilerinin bu konuda gereken önem ve çabayı sarf etmeleri gerekmektedir. Yeniçağda kriz sürecini iyi yönetebilmek ve meydana gelebilecek negatif saygınlığın oluşumunu engellemek üzere yalnızca basın toplantısı düzenlemek veya kurumsal reklam yayınlamak yeterli olmamaktadır ${ }^{34}$. Bunun yanı sıra yeni medya ağlarında da etkili bir biçimde boy göstermek, bu ortam üzerinde krizi etkin

${ }^{34}$ Kadıbeşegil, a.g.e., s.62. 
bir şekilde yönetmek ve saygınlığı muhafaza etmek için birtakım önlemlerin alınması gerekmektedir.

\section{SONUÇ}

Bu makalede sosyal medya ve kurumsal itibar ilişkisi incelenmiştir. Teknolojik gelișmelerin etkisiyle kurumlarda şekillenmekte ve bu gelişmeye ayak uydurmaya çalışmaktadırlar. İnternetin gelişimi ile birlikte artık tüm kurumların kendilerine ait internet siteleri vardır. Bazı kurumlar markalarına özet internet siteleri de açmaktadırlar. Son yıllarda sosyal medyanın gelişmesiyle birlikte kurumlar bu yeni medyaya da giriş yapmışlardır.

Kurumların artan rekabet ortamında var olabilmeleri ve varlıklarını devam ettirebilmeleri ancak güçlü bir kurumsal itibar oluşturmasıyla mümkündür.

$\mathrm{Bu}$ bağlamda kurumsal itibarlarını çevrimiçi ortamlarda da geliştirmek isteyen kurumlar şirketlerine veya alt marklarına ait sosyal medya sayfaları açmakta ve tüketicileriyle direkt bağlantı kurmaya çalışmaktadırlar. Dolayısıyla sosyal medyanın etkin bir şekilde kullanılıp kullanılmadığı, itibar açısından önemli olmaktadır. Bu doğrultuda, özellikle popüler bazı sosyal medya araçlarının doğru ve aktif bir şekilde kullanılmasının altı çizilmelidir. Bu bağlamda işletmeler Facebook, Twitter, Instagram, Pinterest benzeri yeni medya ağlarını kullanarak alıcılarıyla direkt olarak etkileşimde bulunma imkanına sahip olmaktadır. Örneğin birçok kurum “Facebook" hesabı açarak kendine özgü sayfa oluşturmaktadır. Bu sayfa üzerinden ürün ve hizmetleri ile ilgili tanıtıcı bilgiler vermekte ve çeşitli kampanyalar düzenleyerek yeni tüketicileri sayfalarına çekmeye çalışmaktadırlar.

Sosyal medya üzerinde durulması gereken etkili bir güç haline gelmiştir. Bu bağlamda kurum yöneticilerinin bu konuda gereken önem ve çabayı sarf etmeleri gerekmektedir. Bunun yanı sıra yeni medya ağlarında da etkili bir biçimde boy göstermek, yönetmek ve saygınlığı muhafaza etmek için birtakım önlemlerin alınması gerekmektedir. Sosyal medyada olumsuz bir bilgi olumlu bir bilgiye göre daha hızlı yayılmaktadır. Bu nedenle sosyal medya çalışmaları yapııırken bir sosyal medya uzmanı ile çalışmak kurumların yararına olabilir. Sosyal medyada gözde olan bir kurumun kurumsal itibarı da artacaktır. 
KAYNAKÇA

ADECCO, Rapor-2014, Türkiye. 15 Kasım 2016,

http://www.adecco.com.tr/trTR/Documents/Sosyal\%2omedya \%20anketi\%20T\%C3\%BCrkiye\%2ora poru_pdf

AKAR, Erkan, Sosyal Medya Pazarlaması, Ankara: Efil yayınevi, 2010.

ANCA, E. Cretu ve RODERICK, Brodie, "The Influence of Brand Image and Company Reputation Where Manufacturers Market to Small Firms: A Customer Value Perspective", Industrial Marketing Journal, 36, 2007, 135137.

AYDIN, F. Ali, "Kurumsal İtibar Açısından Sosyal Medyaya ilişkin Bir Değerlendirme", Karadeniz Teknik Üniversitesi İletişim Araștırmaları Dergisi, sayı:9, 2014.

AZUA, Maria, The Social factorImmovate, Ignite and Win through Mass Collaboration and Social Networking, IBM Press: NJ, 2010.
BLOSSOM, John, Content Nation Surving and Thiriving as Social Media Changes Our Work, Our Lives and Our Future, Wiley Publishing, Inc.: Indiana, 2009.

BOWD, Ryan, ve BOWD, L. Assessing A Financial Value For A Corporate Entity's Reputation; A Proposed Formula", Research Institute for Business and Management, 2006

BRUNS, Axel and BAHNISCH, Mark. "Social Media: Tools for User Generated Content Social Drivers Behind Growinf Consumer Participation in User-Led Content Generation", State of the Art, Volume 1, March, 2009.

CAMPIRANON, Korn, Managing Reputation in Event Planning Companies, 2007. 15 Kasım 2016, http://eprint.uq.edu.auarchive/o 0004619/01/

CAPOZZi, Louis, "Corporate Reputation: Our Role in Sustaining and Building A Valuable Asset", Journal of Advertising Research, 45(3), 2005, 290-293. 
CRAVENS, S. Karen and OLIVER, G. Elizabeth, "Employees: The Key Link to Corporate Reputation Management",

Business

Horizons. 49(4), 2006, 293-302.

ÇíLDAN, Cihad ve ERTEMiz, Mustafa, "Sosyal Medyanın Politik Katılım ve Hareketlerdeki Rolü", Akademik Bilișim, 2012.

DAVIES, Gary, CHUN, Rosa, SiLVA, Rui V., ve POPER, P. Stuart, Corporate Reputation and Competitiveness. New York: Routledge, 2003.

DIERICKX, I., ve COOL, K. "Asset Stock Accumulation and Sustainability of Competitive Advantage", Management Science, 35, 1989, 1504-1511.

DOWLING, Grahame, "Measuring Corporate İmages: A Review of Alternative Approaches", Journal of Business Research, 17(1), 1988.

DULWORTH, Michael, The Connect effect, Publishers, Inc.:CA, 2008.
ER, Gamze, Sanal Ortamda İtibar Yönetimi, Cinius Yayınları, İstanbul, 2008.
EREN, Veysel ve AYDIN, Abdullah, "Sosyal Medyanın Kamuoyu Oluşturmadaki Rolü ve Muhtemel Riskler". KMÜ Sosyal ve Ekonomik Araştırmalar Dergissi, 16 (Özel Sayı I), 2014, 197- 205.

FIKRIMÜHIM ARAŞTIRMA ŞiRKETi, 15 Kasım 2016,

https://www.fikrimuhim.com/Binary/ Images/Upload/internetarastirmasi/FM_ DAtu\%CC\%88mu\%CC\%88.pdf.

FOMBRUN, C. (1997). ““Indices Of Corporate Reputation: An Analysis of Media Rankings and Social Monitors Ratings, Corporate Reputation Review, 1(4), 1997, 327-340.

GÜÇDEMIR, Yeşim, Sanal Ortamda iletişim-Bir Halkla ilişkiler Perspektifi, Derin Yayınları, İstanbul, 2012. 
HANSEN, Havard, SAMUELSEN, Bendik M., ve SILSETH, Pal R, "Customer Perceived Value in B-T-B Service Relationships: Investigating The Importance of Corporate Reputation", Industrial Marketing Management, 37, 2008, 206-217.

http://www.kigem.com, 10 Kasım 2016.

JONES, Gary H., JONES, Beth H., ve LITTLE, Philiph. L, Reputation as Reservoir: The Value of Corporate Goodwill as a Buffer Against Loss in Times of Economic Crisis. Wester California University, 2007.

KADIBEŞEGIL, Salim, İtibar Yönetimi, MediaCat Kitapları, İstanbul, 2012.

KARA Tolga ve ÖZGEN, Ebru, Sosyal Medya Akademi, İstanbul: Beta Yayıncilık, 2012.
KARA, Tolga, "Sosyal Medya Üzerinde Yeni Nesil Pazarlama ve Türkiye Bilgi \& İletişim Hizmetleri Endüstrisinde Sosyal Ağların Kullanımına Yönelik Bir Araștırma", Global Media Journal Turkish Edition, Cilt 2, Sayı 4, 2012, ss.102-117.

KEH, Heah T. and XIE, Yi, "Corporate Reputation and Customer Behavioral Intentions: The Roles of Trust, Identification and Commitment", Industrial Marketing Management, 38(7), 2009, 732-742.

LACZNIAK, R. N., DECARLO, T. E., ve RAMASWAMI, S. N. "Consumers' Response to Negative Word-OfMouth Communication: An Attribution Theory Perspective", Journal of Consumer Psychology, 11(1), 2006, 57-73.

LAUFER, Daniel and COOMBS, Timothy, "How Should a Company Respond to a Product Harm Crisis? The Role of Corporate Reputation and Consumer Based Cues", Business Horizons, 49(5), 2006, 379-385. 
MARTIN, Greeme and HETRICK, Susan,

\section{Corporate}

Reputations,Branding

and

People Management:

A

Strategic Approach to HR.

Burlington:

ButterworthHeineman

Publications, 2006.

MOONEY, C. Online Social Networking,

Gale, Cengage Learning: Detroit, 2009.

NEWMAN, A.C. and THOMAS, J.G.

Enterprise 2.0 Implementation,

Mc-Graw Hill: New York, 2009.

OKUR, Mehmet E, "Kurumsal Saygınlık Yönetimi", Marmara Üniversitesi

Sosyal Bilimler Enstitüsü

Hakemli Dergisi, 7(26), 2006.

ÖZGEN, Hacer, "Sağlık Hizmetlerinde

Kalite Nedir? Hasta Tatmini

Boyutuyla ilgili Bir

Değerlendirme", Toplum ve

Hekim Dergisi “Hastaneler” Özel

sayısı, C.10, Ankara, 2012.
PELTEKOĞLU, Filiz, Sosyal Medya

Akademi, "Sosyal Medya Sosyal

Değişim". 2012, İstanbul: Beta

Yayıncilık.

SAYLI, Halil ve UĞURLU, Y. Özlem, Kurumsal İtibar ve Yönetsel Etik İlişkisinin Analizine Yönelik Bir Değerlendirme", Süleyman

Demirel Üniv. iỉBF Dergisi, Cilt 12, Sayı 3, 2007, ss.75-96.

TUiK, 20 Kasım 2016, http://www.tuik.gov.tr/PreHaber Bultenleri.do?id=21779

WE ARE SOCIAL, 20 Kasım 2014, January, http://wearesocial.net/

ZENELAJ, Besjon, "Pazarlama Stratejisi Olarak Sosyal Medya IIletişimi Ille Kurumsal İtibarı Oluşturmak: Illetişim Sektöründe Bir Araştırma", (Yüksek Lisans Tezi) T.C. Selçuk Üniversitesi Sosyal Bilimler Enstitüsü, Konya, 2014. 


\section{Summary}

With the effect of technological developments in the 21st century, conditions have changed and they continue to change day by day. Businesses are working to be able to survive in the global competition and maintain their existence. It is only possible for institutions to survive in an intensely competitive environment and to maintain their assets by establishing a strong corporate reputation. Corporate reputation refers to the net emotional response of employees, customers, managers, suppliers, investors, and overall society and other stakeholders as good or bad, weak or strong. Corporate reputation is shaped by the expectations of stakeholders. For example, while employees evaluate businesses based on expectations such as improving working conditions or finding fair and transparent performance criteria, investors' expectations will be more about financial success.

With the development of the internet, institutions have also changed. This new media trend that emerged with the development of social media and the connection of internet with everyday life is an important element in influencing reputation of institutions in a positive or negative direction.

It is indubitable that, those instutions that keep pace with these developments in the global competitive environment will be in the front row with respect to other institutions. Institutions are continuously developing new strategies for customer satisfaction in order to be successful in an competitive market environment. With the popularity of the internet it is critical to establish online communication with consumers. Institutions should produce strategies containing steps to create, improve and preserve corporate reputation.

Inovations and features that came with social media brought new possibilities in terms of institutions. Now Institutions started to follow their stakeholders, learning their expectations, complaints, contentment and developing strategies in accordance with these informations. Therefore, whether or not the social media is used effectively by institutions is of utmost importance in terms of reputation. At this point, especially some popular social media tools should be used correctly and actively. For example, many institutions create their own "Facebook" page. Through this page, they are giving product and service informations and creating campaings. Use of social media in the most effective way in order to create and sustain a positive reputation to survive in an intense competitive environment is a necessity or even an obligation for institutions. Because not only individuals or societies but also institutions have to act in accordance with the "spirit of time". 